\title{
PEMANFAATAN SINGLE FLASH EXTERNAL DENGAN GUIDE NUMBER RENDAH UNTUK PEMOTRETAN RUANG
}

\author{
Bambang M. Soewito dan Kartika K. Wardani \\ Bidang Studi Desain Komunikasi Visual, Jurusan Desain Produk Industri, ITS Surabaya \\ Kampus ITS Keputih, Sukolilo, Surabaya, Jawa Timur 60111 \\ No. Tlp. (+6231) 5994251, No. HP. 081232667670,_E-mail: bb_mardiono@yahoo.com
}

\begin{abstract}
Abstrak
Dalam teknik fotografi, cahaya merupakan elemen dasar dalam pembentukan image. Pemahaman tata pencahayaan saat pemotretan mutlak diperlukan karena akan memengaruhi mutu gambar yang didapat. Optimalisasi pencahayaan pada objek dapat diperoleh dengan cara memahami karakternya. Hal itu bisa dilakukan dengan menggolongkan cahaya berdasarkan sumbernya atau mengenal sifat-sifatnya, juga memahami pola terapan cahaya tersebut. Pemotretan interior merupakan salah satu terapan fotografi yang mengeksplorasi detail objek dan suasana ruangan sehingga suatu saat bias saja dibutuhkan lampu tambahan yang berupa flash. Dalam memenuhi tujuan itu, beberapa di antaranya masih banyak yang membutuhkan penggunaan lebih dari satu titik lampu flash beserta aksesorisnya sehingga akan memengaruhi biaya operasionalnya juga. Pada penulisan ini akan disampaikan hasil percobaan tentang pemotretan ruang yang hanya menggunakan sebuah lampu flash eksternal berintensitas kecil, yang bisa dimanfaatkan secara optimal untuk meningkatkan kualitas foto sehingga dirasa dapat menekan biaya operasional pemotretan.
\end{abstract}

Kata kunci: cahaya, fotografi, ruangan

\begin{abstract}
Application of Single Flash External Using Low Guide Number for Interior Photography. Light is the basic element of photographic technique in formation of the image. Understanding of the lighting system is important when taking the picture, because it will affect the quality of the image. Optimization of the lighting on the object can be obtained by understanding its character. This can be done by categorize light based source, identify light feature and figure out the pattern of the light. Interior photography is one of applied photography which explores the details of the object and the circumstances of the room, so that it needs extra light in the form of flash. To obtain that objective, usually a much needed to use more than one point of the flash and its accessories, so it affect operational costs as well. In this paper, the author presents the results of experiments on interior photography, which by using a small intensity of light from external flash optimally can improve the quality of the image and also reduce costs of interior photo shoot's operasional.
\end{abstract}

Keywords: light, photography, room

\section{PENDAHULUAN}

Fotografi merupakan salah satu dari sekian banyak bentuk media visual yang telah berkembang seiring dengan kemajuan zaman. Hal ini diwujudkan dengan semakin beragamnya alat juga aksesoris yang digunakan, sampai bentuk terapannya dalam suatu media. Secara umum fotografi dapat dibagi menjadi fotografi jurnalistik, fotografi komersial, dan fotografi fine art. Tentu semuanya membutuhkan konsep yang melatarbelakangi terciptanya sebuah karya tersebut. Konsep pemotretan akan 
mengarahkan opini, sehingga harus diperkuat dengan pemahaman teknis yang dipadukan kaidah artistik.

Berbeda dengan bahasa tulis dan lisan, bahasa gambar (dalam hal ini foto) bisa menjadi alternatif dalam penyampaian pesan. Foto dianggap memiliki sifat yang universal sehingga memudahkan khalayak untuk menciptakan persepsi dari sudut pandang pengalamannya. Dengan sifat tersebut, bahasa gambar dapat menjadikan jembatan penting dalam membangun komunikasi. Perlu diingat bahwa sifat bahasa gambaradalahuniversal, yang bisa mengakibatkan timbulnya persepsi yang luas pula. Jadi, saat mengutarakan gagasan harus dilakukan dengan cermat sehingga segala macam hasil foto yang tertuang dapat diasumsi sama oleh publik. Gambar yang dihasilkan dari teknik fotografi sifatnya tidak bergerak (pasif), tetapi untuk mewujudkan gambar yang berkesan bergerak diwujudkan dengan cara mengubah kecepatan rana. Jadi, dalam media foto kesan apa pun bisa dihasilkan atau didapatkan bila dikerjakan berdasarkan konsep dengan pemilihan metode yang tepat.

Penentuan posisi objek dalam bidang gambar juga memengaruhi persepsi orang yang melihat sehingga diperlukan penentuan objek sebagai point of interest gambar. Penataan objek juga bisa didasarkan atas pengaturan komposisi, yaitu tentang warna, bentuk, ukuran, dan tekstur dari objek tersebut.

Selain penempatan objek dalam frame, pertimbangan pengaturan pencahayaan akan memengaruhi hasil yang didapat. Pengaturan pencahayaan dalam fotografi berkaitan dengan penentuan ISO, penentuan kecepatan rana, dan penentuan bukaan diafragma. Kombinasi yang tepat antara ketiganya akan memengaruhi hasil gambar yang didapat, dari kesan gelap/terang gambar hingga efek kedalaman ruang. Selain itu, yang harus diperhitungkan juga adalah arah datangnya cahaya, hadirnya efek highlight, ataupun shadow pada objek merupakan salah satu bentuk yang ditimbulkan karena posisi cahaya. Beragamnya hasil foto yang didapat, tentu akan memengaruhi tingkat persepsi orang yang melihat gambar tersebut.

Dalam fotografi, pencahayaan atau lighting dapat digolongkan ke dalam berbagai topik bahasan. Umumnya pembahasan tersebut berkaitan dengan: (1) sumber cahaya. Bila ditinjau dari sumbernya, cahaya yang ada bisa dibagi menjadi dua, yaitu cahaya alam (natural light) dan cahaya buatan (artificial light), yaitu cahaya yang sengaja ditambahkan untuk keperluan pemotretan, seperti penggunaan flash, strobist, studio flash/ monoblok, dan aksesoris pendukung lainnya. Walau sifatnya buatan, artificial light untuk kebutuhan fotografi karakternya sudah didesain hingga menyerupai natural light; (2) fungsi pencahayaan: (a) main light, cahaya utama yang diprioritaskan untuk pembentukan objek, (b) fill-in light, cahaya bantu atau cahaya tambahan yang digunakan untuk penyeimbang sinar, dan (c) effect light, cahaya yang diaplikasikan untuk menimbulkan kesan tertentu dari objek; (3) sifat cahaya. Berdasarkan sifatnya, cahaya dapat dibagi menjadi: (a) hard light, cahaya yang sifatnya keras mengenai objek, yang ditandai dengan hadirnya shadow atau bayangan yang pekat pada objek. Biasanya terjadi saat cahaya langsung menerpa objek, (b) semi soft light, bisa dihasilkan dengan cara memberikan tambahan aksesoris pada lighting sehingga sinar yang mengenai objek tidak terlalu keras sifatnya, (c) soft light, cahaya yang bersifat lembut. Hal tersebut dilakukan untuk mendapatkan penyinaran yang merata pada objek, dengan cara memantulkan sinar atau memberi penghalang pada penyinaran, berupa bahan yang transparan (tembus cahaya); (4) pola 
pencahayaan: (a) broad light (cahaya menyebar), (b) narrow ligth (cahaya terarah/menyempit), (c) spot light (cahaya spot).

Selain hal-hal tersebut, tidak kalah penting adalah mengetahui rasio pencahayaan. Dengan pengaturan rasio yang tepat, pemotretan bisa diwujudkan sesuai dengan yang direncanakan. Contoh: antara main light dan effect light, maka rasio intensitas effect light harus lebih besar. Jika rasio main light lebih besar, kesan yang ditimbulkan pada effect light tidak akan terlihat hasilnya, begitu juga seterusnya (Adimodel, 2009:24-25).

Dari hal tersebut dapat diperoleh acuan, yaitu effect light $>$ main-light $>$ fill-in light. Intensitas cahaya yang dihasilkan effect-light harus lebih kuat daripada main-light, dan kuat cahaya pada main-light harus lebih besar daripada fill-in light. Demikian yang perlu diketahui adalah rasio perbandingan antara titik lampu satu dan yang lain harus terukur dengan cermat intensitasnya.

Penggunaan beberapa titik pencahayaan dalam suatu pemotretan setidaknya juga akan memengaruhi banyak pertimbangan karena akan memengaruhi pola bayangan yang dihasilkannya. Pada intinya semakin sedikit titik cahaya yang digunakan, semakin sederhana pula masalah pencahayaan dalam sebuah pemotretan dapat diatasi.

Dalam menghasilkan karya fotografi selain kematangan konsep, harus ditunjang pula dengan berbagai kreativitas, eksperimen, dan pengetahuan teknik yang tepat. Kepekaan dalam pemilihan objek dapat dioptimalkan sehingga penampilan hasil foto dapat mewakili ide penciptaan sesuai dengan tujuan dan kegunaannya.

Proses penciptaan sebuah karya tidak lepas dari faktor yang menjadi latar belakangnya, yakni faktor objek. Objek ini adalah segala hal yang inspiratif, misalnya objek itu bisa bersifat psikologis, cinta, keindahan, dan kesedihan. Singkatnya pemilihan objek tersebut merupakan refleksi dari gagasan yang ada di sekitar untuk mendasari dan mengawali terciptanya sebuah karya.

Pemotretan interior merupakan salah satu terapan fotografi yang juga memiliki tujuan untuk mengungkapkan gagasan dengan merekonstruksi, juga mengoreksi situasi ruangan untuk memenuhi tujuan tertentu. Kegiatan merekontruksi yang dimaksud adalah kegiatan pembentukan kesan sehingga menjadi situasi ruangan yang representatif, misalnya ruang tamu yang berkesan suram direkonstruksi menjadi berkesan lebih hangat dan membentuk kesan ruang yang luas. Sementara itu, kegiatan mengoreksi lebih menitikberatkan pada menutup area-area yang kurang pantas untuk diekspos, mengurangi distorsi, dan menonjolkan bagian-bagian yang menarik. Hingga akhirnya mendapatkan suasana yang diinginkan dari penggunaan beberapa lighting yang ada di sekitar. Pada umumnya, hal tersebut dilakukan guna meningkatkan kualitas image foto yang dihasilkan. Beberapa aplikasinya dapat digunakan untuk tujuan-tujuan komersial seperti pemotretan untuk materi iklan dan alat bantu representasi tim marketing.

Pemilihan tema dalam proses ini didasari atas pengetahuan prinsip fotografi dan objek yang akan difoto. Studi tentang karakter objek sampai penempatan lighting dan angle pemotretan akan menghasilkan kesempurnaan hasil foto. Tujuannya agar nilai dokumentasi pada hasil foto tersebut banyak memberi keuntungan, misalnya dalam pemotretan ruangan atau interior.

Usaha penciptaan sebuah karya akan mempunyai landasan yang kuat jika disertai kajian terhadap sumbernya sehingga 
dapat membangun pengalaman baru dalam berekspresi. Kajian dapat berupa literatur kepustakaan, hasil observasi, dan pengamatan terhadap objek tertentu.

\section{CITRA DALAM FOTOGRAFI}

Fotografi merupakan perpaduan antara teknologi dan seni, dengan metode perekaman gambar: cahaya - objek - kamera - media peka cahaya. Kamera merupakan alat perekam gambar. Fitur-fitur kamera juga memiliki beragam teknis yang dapat diaplikasi sehingga banyak memunculkan berbagai macam variasi teknik yang dapat menunjang visualisasi karya fotografi saat ini. Koreksi pencahayaan dan komposisi objek yang tepat akan memengaruhi hasil yang diharapkan. Mencari keseimbangan pencahayaan pada saat pemotretan mutlak diperlukan sehingga hasilnya tidak terkesan over exposure ataupun under exposure. Ada tiga unsur yang menentukan exposure, yaitu: (1) kepekaan sensor/film (ISO/ASA/DIN/JIS), (2) kecepatan rana (shutter speed), dan (3) bukaan diafragma $(f)$.

Selain untuk menyeimbangkan cahaya yang masuk ke film/sensor, penentuan kalkulasi ketiganya juga akan memengaruhi efek foto yang dihasilkan, misalnya untuk kebutuhan skala ruang tajam pada objek, prioritas utamanya adalah menentukan diafragma. Untuk skala kecepatan, fungsi pada rana ditentukan dahulu sebelum diafragma. pada setting ISO. Hal ini akan berdampak pada ketajaman gambar yang dihasilkan.

\section{FLASH}

Flash yang biasa dipakai dalam pemotretan dibedakan menjadi dua jenis, yaitu flash internal (built-in flash) dan flash eksternal (portable flash). Disebut flash internal karena flash ini permanen/fiturnya ada pada kamera, sedangkan flash eksternal adalah flash yang terpisah dari bodi kamera. Intensitas flash internal yang rendah banyak digunakan sebagai fill-in light, walau tidak menutup kemungkinan jika tidak ada satu penerangan saat pemotretan, flash ini berubah fungsi sebagai main-light.

Intensitas flash eksternal biasanya lebih tinggi dibanding flash internal. Hal ini dikarenakan flash eksternal mempunyai sumber tenaga sendiri. Dari segi volume, bobot dan ukuran flash eksternal dinilai lebih besar daripada flash internal sehingga butuh tempat lagi untuk dibawa. Karakter flash eksternal juga berbeda antara satu flash dan flash lain karena produksinya ada yang dari brand independen ataupun pabrikan (satu produksi dengan kamera).

Flash eksternal yang digunakan sebagai key light (cahaya utama) dapat menghasilkan hasil foto yang sangat menarik dengan cara exposure compensation (EC) menggunakan kecepatan kilatan lampu untuk menjadikan gelap atau terangnya latar belakang. Flash internal dapat juga menjadi fill light pada scene fotografi yang memiliki kontras tinggi. Hasilnya akan memperoleh highlight yang tepat dengan menipiskan garadasi dengan bayangan dengan cara mengekspos detail bayangan yaitu mengisi dengan cahaya flash bayangan gelap dan dynamic range rendah (Peterson, 2011:66-71).

Biasanya untuk dapat menyinkronkan kecepatan rana dan kecepatan kilatan lampu, flash ini ditaruh dalam sebuah fitur yang disebut hot-shoe. Tiap-tiap kamera mempunyai titik syncro yang berbeda baik tempat dan jumlahnya, begitu juga titik syncro yang berada pada flash sehingga tidak semua lampu kilat bisa digunakan langsung pada setiap kamera. 


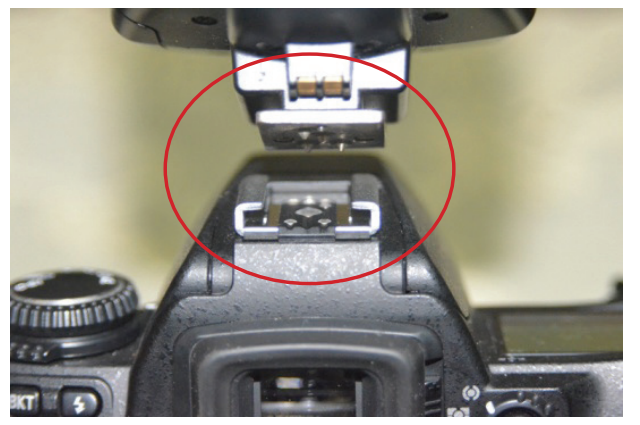

Gambar 1. Hot shoe pada kamera
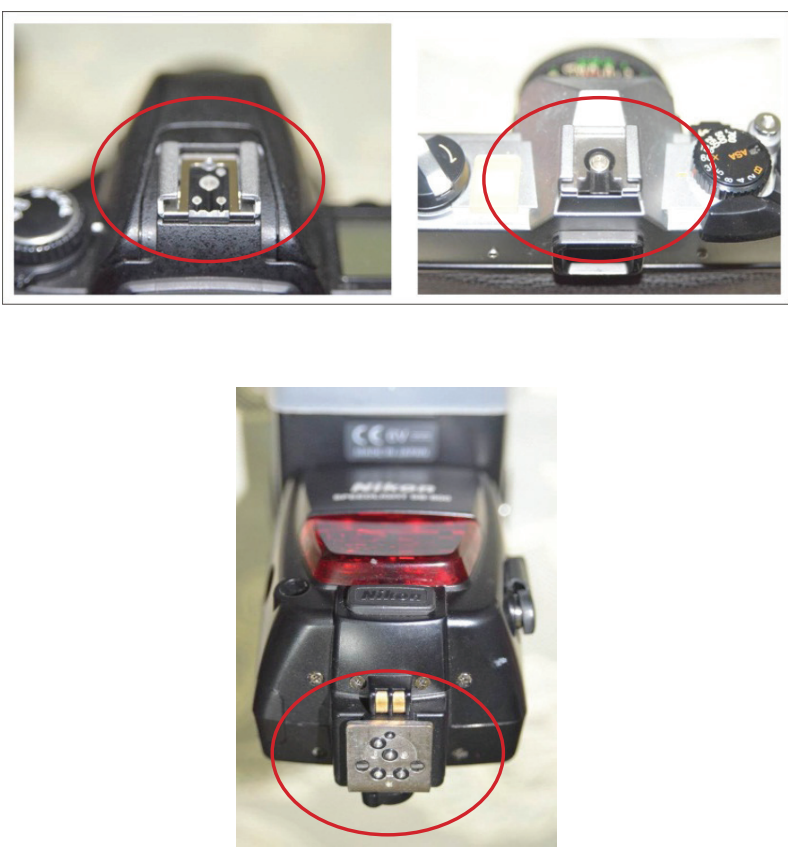

Gambar 2. Titik syncro pada bodi kamera dan flash

Walaupun kegunaannya sama untuk penerangan, kedua flash tersebut mempunyai metode aplikasi yang berbeda satu sama lain. Ada yang sistemnya manual, ada yang otomatis, keduanya memerlukan pemahaman dalam aplikasinya. Dengan flash bersistem manual, hendaknya diketahui kalkulasinya, yakni:

$$
\mathbf{f}=\mathbf{G N} / \mathbf{m}
$$

Dengan mengetahui GN (kekuatan intensitas sinar pada flash), m (jarak antara titik lampudenganobjek)diharapkanbisamendapatkan f (diafragma) yang terpasang secara normal (dengan hasil tidak under exposure ataupun over exposure). Sementara penentuan untuk kecepatan rana, disesuaikan dengan metode pemotretannya, yaitu selama masih syncro dengan kecepatan flash. Untuk flash yang bersistem otomatis, kemudahannya tidak menggunakan kalkulasi saat pemotretan berlangsung karena di dalamya terdapat sensor yang dapat mengkalkulasi jarak objek (Prakel, 2007:90-91).

Fungsi dan tujuan fotografi ruangan sering dipandang membutuhkan banyak properti alat sehingga biaya operasionalnya jadi lebih tinggi. Penggunaan alat penunjang fotografi seperti penggunaan beberapa titik lampu dan kelengkapan akesoris lampu yang digunakan, dianggap dapat membantu membentuk suasana yang berbeda sehingga hasilnya sesuai dengan rencana. Seorang fotografer dalam praktiknya diharapkan bisa memahami dan menguasai aplikasi pencahayaan dengan cermat, selain paham tentang alat dan objek tentunya.

Cahaya dalam fotografi bisa dibagi berdasarkan sumbernya, yaitu natural light (cahaya alam) dan artificial light (cahaya buatan). Kesemuanya bisa dipakai dan dikreasikan sesuai keadaan bahkan bisa digabung untuk menghasilkan suasana tertentu. Kreasi untuk menghasilkan cahaya pada dasarnya bisa dilakukan untuk indoor ataupun outdoor, dengan sifat penerangan yang terusmenerus (continue) dan sesaat (flash).

\section{KONSEP PENCAHAYAAN RUANG}

Sistem pencahayaan dalam sebuah ruang mampu memunculkan kesan tertentu. Sumber cahaya tidak hanya berasal dari alam seperti cahaya matahari ataupun pantulan sinar bulan, tetapi juga pencahayaan buatan. Penggunaan sistem pencahayaan yang digunakan dalam ruangan memiliki tujuan ekonomis dan tujuan estetika. Sistem pencahayaan yang 
memenuhi tujuan ekonomis merupakan sistem pencahayaan ruang yang banyak diterapkan. Aplikasi secara umum di sebuah rumah tinggal, yaitu dengan menggunakan lampu pijar standar tungsten yang memancarkan cahaya putih ataupun menggunakan lampu compact fluorescent dalam suatu ruangan.

Sistem pencahayaan untuk memenuhi tujuan estetika menggunakan pendekatan layer pencahayaan. Tiap layer pencahayaan memiliki peran dalam menghasilkan komposisi yang harmonis di sebuah ruang. Mendesain layer pencahayaan antara lain dengan memerhatikan layer pencahayaan ambient, layer pencahayaan di area kerja, layer lampu sorot, dan layer dekoratif. Layer pencahayaan ambient merupakan penyedia keseluruhan pencahayaan. Layer pencahayaan area kerja memberikan pencahayaan dalam aktivitas kerja yang terdiri atas luminair atas dan luminair bawah. Luminair atas dapat berupa lampu gantung, downlight, dan troffer. Luminair bawah meliputi lampu meja, lampu berdiri, dan lampu lemari kerja. Lampu downlight merupakan sistem pencahayaan area kerja yang banyak dialihfungsikan untuk berbagai kebutuhan.

Di antara kedua layer tersebut, terdapat layer lampu sorot yang bertujuan untuk menerangi fitur dan benda pameran. Layer lampu sorot terdiri atas pencahayaan track dan tersembunyi. Track pencahayaan lampu sorot biasanya digunakan untuk benda pameran di museum atau galeri. Lampu sorot tersembunyi dapat disetel, sebagai wallwasher, lampu sorot tunggal, dan perlengkapan teater.

Layer dekoratif menganggap sistem pencahayaan sebagai hiasan yang dapat menarik perhatian dan menegaskan gaya atau menampilkan fitur tertentu. Layer ini sangat penting selain digunakan sebagai ornamen ruangan juga memiliki peran yang sangat penting dalam desain interior dan ruangan bertema. Contoh layer ini adalah penggunaan lampu gantung kristal. Fotografi interior tidak hanya menggunakan cahaya yang telah disediakan ruang, namun juga mampu menyediakan layer pencahayaan baru yang dapat lebih menghidupkan suasana ruang tanpa penambahan spot lampu yang bersifat permanen (Karlen and Benya, 2007:55-57).

\section{ELEMEN INTERIOR}

Elemen interior merujuk pada semua benda yang dapat dipindahkan dan dapat membentuk kesan yang dianggap dapat melengkapi ruang. Penambahan elemen interior disesuaikan dengan kebutuhan ruang dan bagaimana aktivitas di dalamnya. Elemen interior yang dimaksud adalah termasuk furniture, material interior, pencahayaan, aksesoris, lukisan dan patung, dan desain sistem (Friedmann, Pile, and Wilson, 1976:203).

Pada pengaplikasian rumah tinggal terutama pada ruang tamu, pada umumnya terdapat furniture standart yang dapat digunakan untuk menerima tamu mulai dari empat (4) orang yang dilengkapi pencahayaann dasar. Ruang tamu dalam penggunaan rumah tinggal memiliki sifat semipublik. Aktivitas dalam ruang ini berhubungan dengan menerima atau menjamu tamu.

Penampilan dari ruang tamu sebagai objek fotografi tidak akan menampilkan informasi yang menarik apabila tidak dilengkapi dengan elemen interior selain furniture dan pencahayaan dasar. Dibutuhkan berbagai aksesoris penunjang sebagai elemen estetis interior seperti lampu duduk, taplak, bantal hias, dll.

Pemanfaatan elemen-elemen interior dalam pemotretan ruang sangat berhubungan 
dengan penggunaan sistem pencahayaan. Dalam pemotretan interior, aksesoris menjadi sangat fungsional dan sangat penting untuk digunakan. Sistem pencahayaan yang ada akan menonjolkan properti interior sehingga areaarea yang dianggap kosong dan cenderung gelap dapat diekspos menjadi satu kesatuan hasil yang estetis.

\section{METODE}

Metode optimalisasi single flash eksternal $G N$ kecil dalam pemotretan ruangan ini berdasarkan hasil eksperimen. Dalam pemotretan ruangan yang mempunyai properti seperti mebel, fotografi ruangan membutuhkan beberapa titik cahaya tambahan yang digunakan untuk menonjolkan bentukan objek. Oleh sebab itu, pada awal percobaan ini dilakukan pengkajian materi fotografi, seperti survei lokasi, pengamatan ruangan, pendataan aksesoris, pengamatan cahaya yang tersedia, dan waktu yang tepat untuk pengambilan gambar.

Lokasi dan ruangan yang dipilih berupa rumah dengan luasan terbatas atau apartemen tipe studio. Pemilihan area dengan ukuran terbatas diwujudkan sebagai target penyelesaian masalah, yaitu menampilkan kondisi pemotretan yang kurang optimal untuk pemotretan. Permasalahan yang mungkin timbul di antaranya adalah tidak dapat membawa banyak kru dan jumlah alat yang akhirnya terbatas.

Peralatan yang digunakan tidak terlalu banyak. Selain kamera dan flash eksternal, peralatan tambahan yang dibutuhkan adalah tripod (penyangga kamera). Untuk memberikan kesan, di ruang tamu diberikan tambahan properti, di antaranya vas bunga, taplak meja, toples kue, dan bantal kursi sebagai penunjang objek.
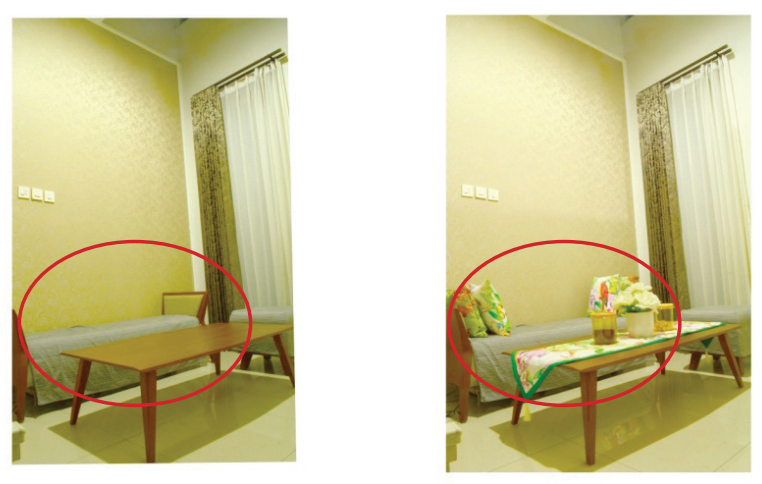

Gambar 3. Perbandingan ruangan tanpa properti dan dengan properti

Pencahayaan yang tersedia di ruang tamu rata-rata berupa cahaya utama berwarna putih dan bisa ditambahkan cahaya spotlight berwarna kuning. Angle kamera yang digunakan mengarah ke jendela sebagai aplikasi penambahan effect light yang ditempatkan di luar ruangan.

Pada saat pemotretan dengan pencahayaan yang seadanya, indikator lightmeter menunjukkan waktu yang diperlukan rana di bawah satu detik. Dengan demikian, eksperimen yang dilakukan adalah mencari exposure yang normal dengan cahaya tersebut. Setelah mengetahui jumlah cahaya yang masuk, percobaan berikutnya adalah memberikan effect light dengan cara memberikan spot-spot tertentu di bagian-bagian objek. Spot cahaya tersebut diterapkan selain memberikan informasi detail objek, juga dirasa bisa menambah kesan pada foto.

Dalam aplikasinya, beberapa hal yang dilakukan adalah: (1) menentukan derajat kemiringan flash sehingga spot yang diharapkan sesuai dengan polanya, (2) menentukan titiktitik pencahayaan pada beberapa objek, hal ini dilakukan untuk mengkalkulasi kuat sinar yang rawan overexposure, (3) menentukan berapa waktu yang diperlukan pada saat memberikan spot-spot pencahayaan, (4) mengombinasi 
pencahayaan, antara cahaya ruang dan cahaya flash, (5) menentukan waktu pemotretan yang menggunakan sarana bulb.

\section{PEMBAHASAN}

Percobaan ini menggunakan ruang tamu berukuran 3 x 2,5 meter persegi. Pemotretan ruang yang minim tidak dapat membawa banyak kru dan peralatan yang terlalu besar. Lampu flash eksternal berintensitas kecil merupakan sarana yang dapat dimanfaatkan secara optimal untuk meningkatkan kualitas foto dan dapat menekan biaya operasional pemotretan.

Pemotretan dilakukan pada saat malam hari, dengan memanfaatkan pencahayaan yang ada di ruang. Beberapa kali pemotretan dengan kombinasi pencahayaan yang berbeda dilakukan untuk menganalisis pencahayaan sekitar. Diketahui bahwa warna-warna cahaya yang terpancar mempunyai intensitas yang berbeda sehingga memungkinkan penyebaran cahaya yang ada beragam polanya. Adanya bayangan menyebabkan beberapa spot tidak terekam detailnya sehingga nilai informasinya berkurang.

Untuk mendapatkan cahaya yang sifatnya menyebar perlu digunakan beberapa teknik, antara lain bounce dan aplikasi diffuse light. Langkah berikutnya adalah mengetahui sifat reflektor yang ada di sekeliling ruangan. Pengaruh reflektor didasari atas jenis bahan, warna, luasan, dan tekstur.

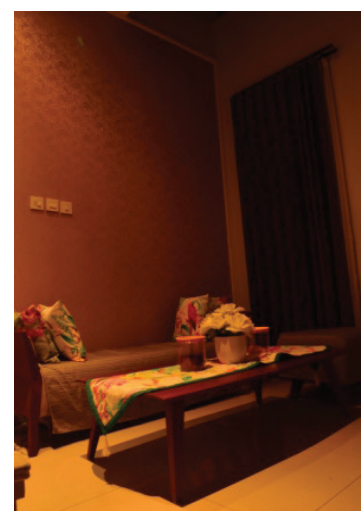

(a)

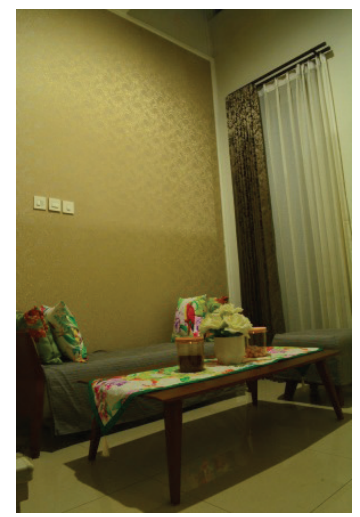

(b)

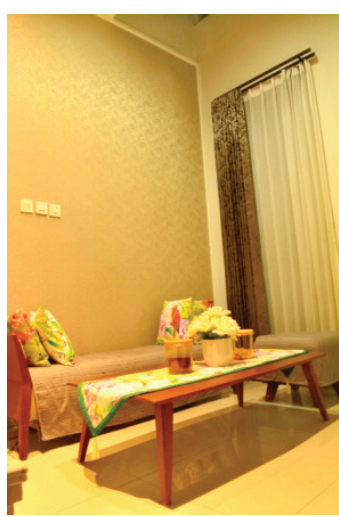

(c)

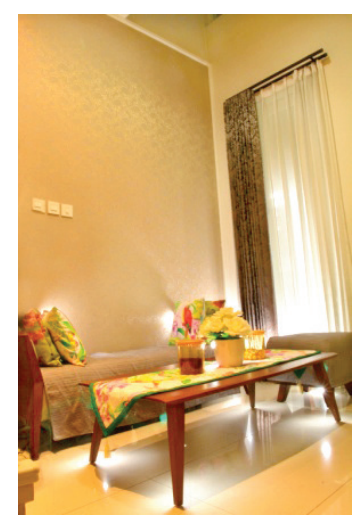

(d)
Gambar 4. Eksperimen cahaya

Ada beberapa cara teknik bounce untuk mendapatkan cahaya yang sifatnya lembut merata, yaitu: (a) ceiling bounce, yaitu memantulkan cahaya dari flash ke permukaan yang lebih luas, seperti langit-langit, (b) card bounce, pada beberapa jenis flash eksternal biasanya disertakan card diffuser yang dipasang pada bagian depan flash, dan (c) wall bounce, cahaya yang diperoleh dari pengaruh warnawarna dinding yang mengelilingi objek. Teknik bounce pada dinding sangat mengkontaminasi objek fotografi dan menampilkan pesan yang sangat berbeda dengan yang diinginkan. Apabila cat dinding memiliki warna yang cerah dan mencolok seperti pink, nantinya kan mempengaruhi pada warna kulit, pakaian dan sekeliling . Sedangkan apabila menginginkan cat dinding yang tidak terlalu berpengaruh dengan hasil cahaya akan lebih baik menggunakan warna putih atau putih tulang (Peterson, 2011:90-92).

Lampu flash eksternal yang digunakan bersistem manual sehingga bisa memosisikan jarak antara lampu flash dan objek secara konsisten. Dengan mengetahui $G N$ dan jarak objek, akhirnya didapat angka diafragma yang tepat menghasilkan cahaya yang sesuai dengan kebutuhan. 
Penjelasan gambar yang didapat sebagai berikut:

Gambar (a), menggunakan eksperimen spotlight kuning dua titik lampu, maka cahaya yang didapat polanya terarah. Cahaya yang dihasilkan intensitasnya rendah sehingga belum mampu menjangkau area tertentu, informasi detail objek jadi terbatas.

Gambar (b), menggunakan lampu utama berwarna putih, diletakkan $90^{\circ}$ derajat vertikal, maka sinar yang didapat sifatnya menyebar. Akan tetapi, karena itensitasnya kecil semakin ke bawah sinarnya makin berkurang. Hal tersebut berimbas juga pada bayangan yang berada di bawah objek menjadi semakin gelap.

Gambar (c), menggunakan kombinasi penyinaran dari kedua hal tersebut ditambah bounce ceiling, dengan tujuan untuk meratakan sinar. Pada flash juga diberi diffuser, harapannya agar cahaya yang dikeluarkan dari lampu kilat tidak terlalu keras.

Gambar (d), menggunakan cahaya kombinasi, yang dipadukan dengan flash dengan pola spot di bagian-bagian tertentu objek sehingga cahaya yang dihasilkan lebih bervariasi. Dengan tambahan beberapa pola yang dihasilkan dari flash setidaknya meminimalkan bayangan yang ada, jadi nilai informasi dari detail objek lebih tercipta.

Hasil yang lain:

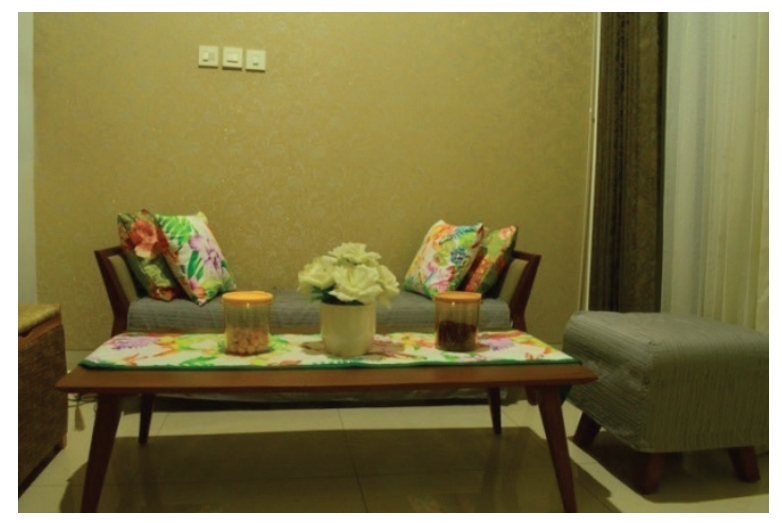

Gambar 5. Tanpa aplikasi flash eksternal

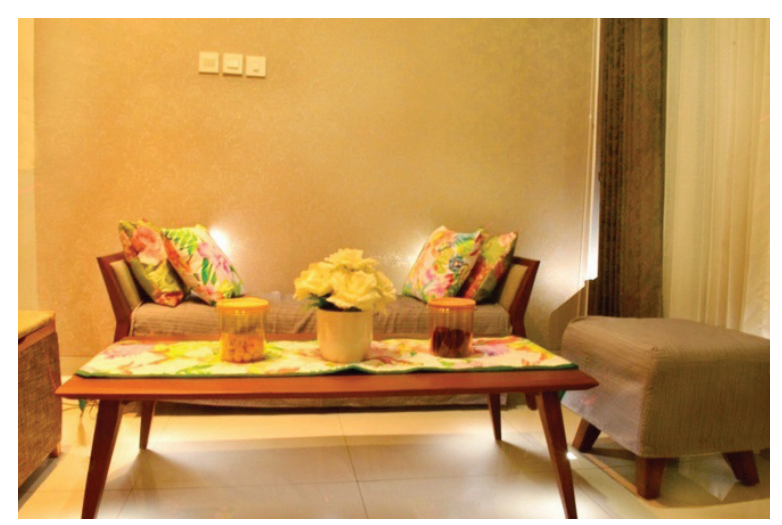

Gambar 6. Penggunaan aplikasi flash eksternal

Berdasarkan hasil foto-foto tersebut, hal yang perlu diperhatikan adalah: (1) sudut pemotretan, (2) karakter cahaya sekitar, (3) kekuatan cahaya flash, (4) pola cahaya flash, dan, (5) penempatan elemen estetik interior.

\section{SIMPULAN}

Sebuah pemotretan membutuhkan kejelian dalam mengamati objek. Hal ini juga dipengaruhi oleh penempatan pencahayaan yang optimal. Tiap cahaya yang terpancar dari berbagai sumber mempunyai karakter yang berbeda sehingga efeknya juga akan memengaruhi hasil foto yang diperoleh. Perubahan-perubahan yang terjadi pada hasil foto antara lain perubahan warna, pola gelap terang, dan kontras gambar.

Penggunaan artificial light, dalam hal ini flash eksternal mempunyai fungsi sebagai main light, fill-in light, dan effect light. Dengan demikian, penerapannya dapat disesuaikan berdasarkan situasi dan kondisi tempat pemotretan. Keuntungan menggunakan single flash eksternal, antara lain: (1) dapat digunakan setiap saat, (2) bentuk portable sehingga bisa digunakan di tempat yang tidak terjangkau cahaya, dan (3) konektor antarflash.

Beberapa teknik pemotretan bisa diterapkan, terutama untuk pemotretan interior. Perlunya melakukan survei dan analisis objek 
sebelum pemotretan akan meminimalisasi kesalahan yang terjadi sehingga waktu yang diperlukan menjadi lebih efisien. Bermacam teknik pemotretan dengan menggunakan flash dapat dilakukan dengan harapan agar mendapatkan hasil yang terbaik.

\section{KEPUSTAKAAN}

Adimodel. 2009. Lighting for Beauty. Jakarta: Elex Media Komputindo.

Friedmann, Arnold; John F. Pile, and Forrest Wilson. 1976. Interior Design: An Introduction to Architectural Interiors. United States of America: American Elsevier Publishing Co. Inc.

Karlen, Mark and James Benya. 2004. Lighting Design Basics. John Wiley \& Sons, Inc. New Jersey Terjemahan. Diana Rumagit. 2007. Dasar-Dasar Desain Pencahayaan. Jakarta: Penerbit Erlangga.

Peterson, Bryan. 2011. Understanding Flash Photography: How to Shoot Great Photographs Using Electronic Flash. New York: Amphoto Books.

Prakel, David. 2007. Basic Photography 02: Lighting. AVA Books. Switzerland. 